\title{
The caisson - review of a unique wooden construction typology in China
}

\author{
Corentin Fivet \\ École Polytechnique Fédérale de Lausanne, Fribourg, Switzerland \\ Jingxian Ye \\ Shanghai, China \\ Peiliang $\mathrm{Xu}$ \\ Ninghai County Cultural Heritage Administration Office, Zhejiang, China
}

\begin{abstract}
The caisson is a wooden construction system that covers opera stages for rain protection and sound control. Caissons in China display a diverse range of geometric expressions, delicate manufacturing, structural behaviours, and acoustic qualities. Despite their uniqueness and patrimonial interest, very little literature is known to exist, and it lacks comprehensiveness. First, this paper attempts to compile for the first time a comprehensive list of publications on caissons. Fifteen sources are identified, among which six papers address the origin and interpretation of douba and spiral caissons. In addition, other types are here recorded, based on an original field research in Zhejiang and Shanxi provinces. Following this survey, the paper also suggests a classification for caisson types according to their geometries, construction process, and structural behaviour. This classification is further supported by the interviews with a local carpenter master who specialized in the renovation and component replacement of caissons. Considerations on carving artistries, painting, and pest control are also given eventually. As a result, this study brings forward the caisson's diversity, fineness, and significance for the history of wood joinery construction.
\end{abstract}

KEYWORDS: 12th-19th centuries, China, Wood-only-construction, Typology, Construction Technology

\section{INTRODUCTION}

In China, a large amount of the world's persistent architectural heritage in wood-only construction has been preserved for several generations. Numerous ingenious wooden construction typologies have been developed and applied in the history. The caisson is a typical architectural element that is widely found in the ceilings of temples, pagodas, palaces, and theatres.

The caisson is a richly decorated sunken 'dome' with a round top and a square bottom set into the ceiling and assembled by a large set of small wooden pieces using pure face-to-face contact connections. It is usually applied at the centre of the building, directly above the religious statue, main throne, or opera stage. Its uncommon technical refinement was proportional to the sought value and authority of the space that it was intended to cover. It is consequently one of the most complex and exquisite parts of Chinese historical architecture (Kaiying 2009). For instance, a douba caisson is built on the top part of the pagoda of Fogong Temple (Mingda 1966), the oldest and highest fully wooden pagoda still in place.

The literal meaning of the caisson (Chinese: 藻井 ; pinyin: zăojǐng) in Chinese is 'algae well'. 'Algae' refers to the aquatic plants, and 'well' means the water source. Therefore, the caisson is traditionally the symbol of a steady flow of water, hoping to suppress the trouble caused by the fire-devil and to protect the safety of the wooden buildings.

The surviving caisson examples in China are mainly distributed in the Shanxi province (north) and the Zhejiang province (south). In order to form a comprehensive understanding of this typical wooden construction typology, a field investigation on the existing caissons in North and South China has been carried out in 2017.

\section{FIELD INVESTIGATION OF SURVIVING CAISSONS IN CHINA}

\subsection{Opera caissons in North China}

The existing caissons in North China were principally built in the ancient official buildings. In addition to temples, pagodas and palaces, caissons were widely adopted in the opera stages (Fig. 1) of official temples. Operas were performed not only for the civilian population but also for the gods. Most of the ancient opera stages and caissons were constructed in the Yuan Dynasty (1271-1368) and the early Ming 
Dynasty (1368-1644). Their prevalence is closely related to the prosperity of the opera culture since the Yuan Dynasty. Compared to the standard caisson type mentioned in the earliest Chinese architecture monograph Yingzao Fashi, Treatise on Architectural Methods (Jie 1110), the caissons of this period have developed greatly in the Shanxi province, with more

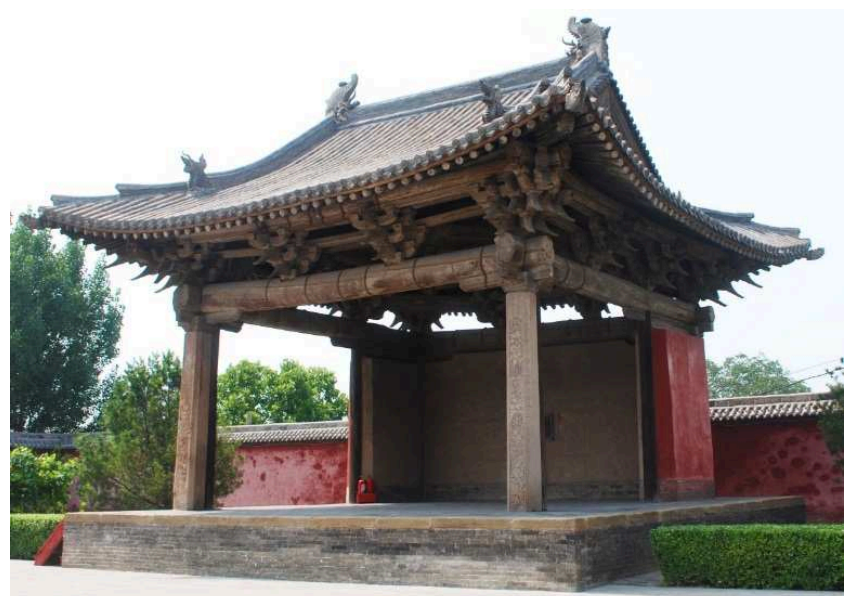

Figure 1. Opera stage of Niuwang Temple, built in 1283. Width: 7.45 m; Depth: 7.42 m; Height: 3.79 m. Ref. SX-01A C Jingxian Ye

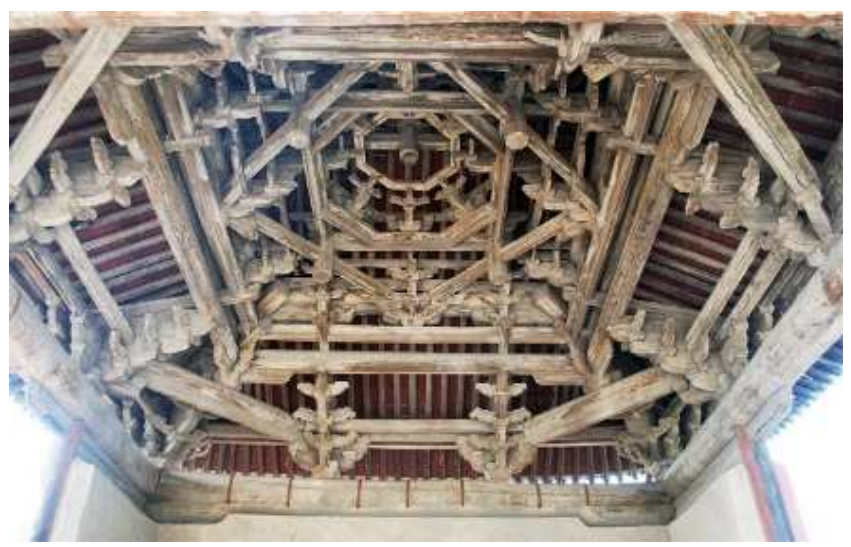

Figure 2. Caisson in Niuwang Temple, built in 1283. Width: 7.45 m. Depth: 7.42 m. Height: 3.79 m. Ref. SX-01A (C) Jingxian $\mathrm{Ye}$

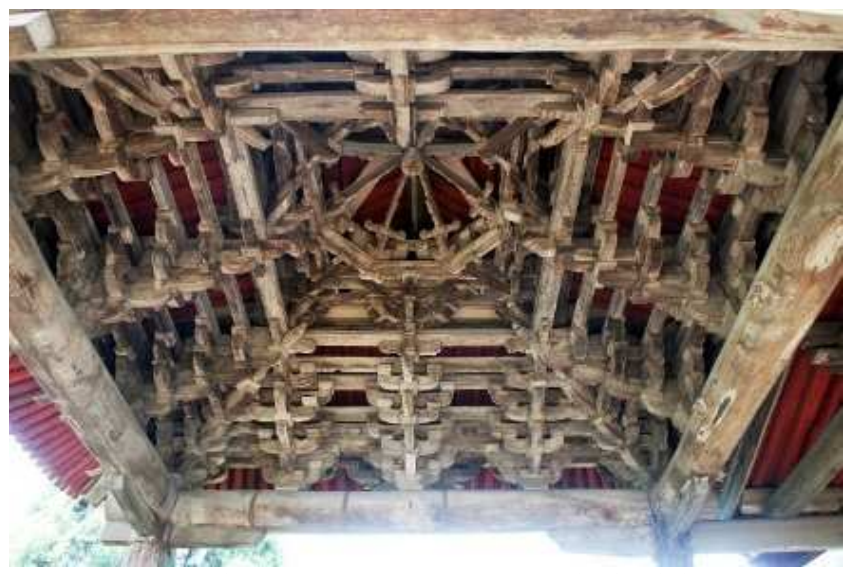

Figure 3. Second caisson in Niuwang Temple, built before 1283 . Ref. SX-01B (C) Jingxian Ye expressive geometries and complicated construction (Figs. 2-5).

From the mid-Ming dynasty (sixteenth century), the caissons of opera stages were increasingly simplified (Fig. 6). This series of caissons has no proper name in literature. 'Reciprocal' will be adopted to describe these anonymous northern caissons in this article, because the reciprocal principle was applied frequently.

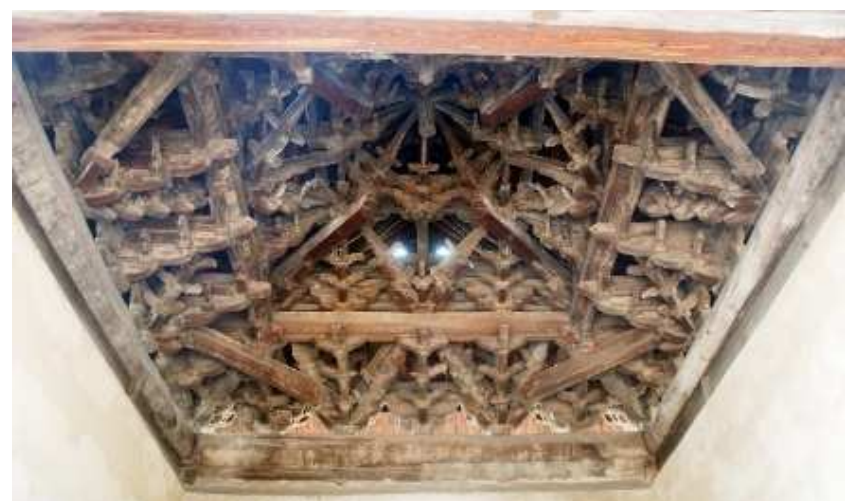

Figure 4. Caisson in Dongyang Temple, built in 1345. Width: 8.04 m. Depth: 7.90 m. Height: 4.43 m. Ref. SX-02 (C) Jingxian $\mathrm{Ye}$

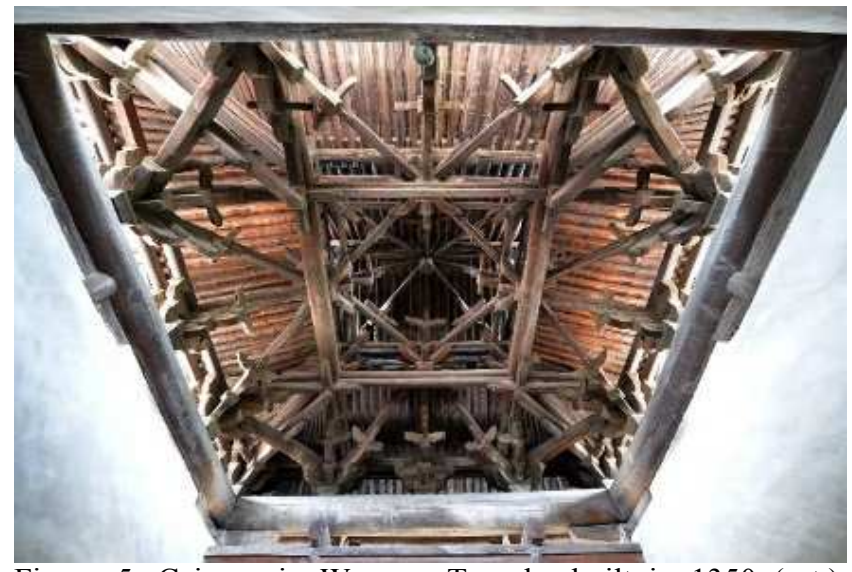

Figure 5. Caisson in Wangqu Temple, built in 1350 (est.). Width: 7.37 m. Depth: 6.83 m. Height: 4.14 m. Ref. SX-03 (C) Peiliang $\mathrm{Xu}$

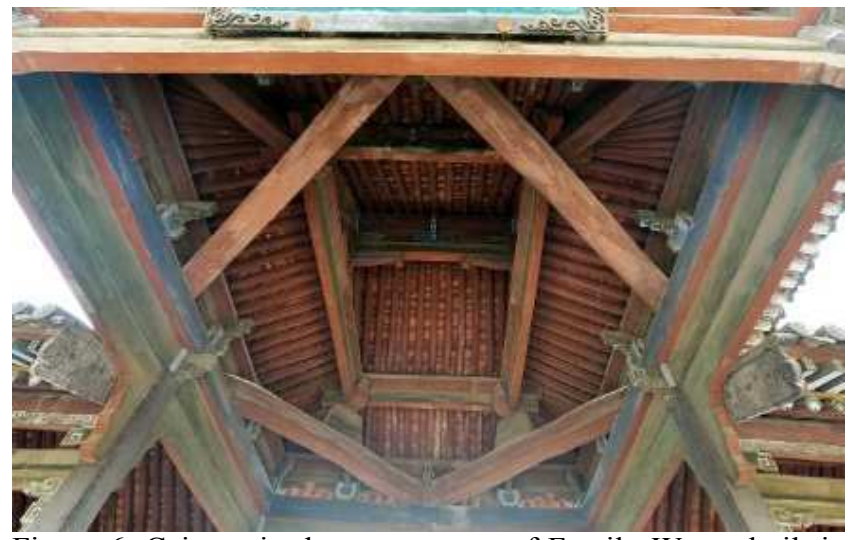

Figure 6. Caisson in the opera stage of Family Wang, built in 1700 (est.). Ref. SX-04 (C) Peiliang Xu 


\subsection{Caisson in South China}

In the south part of China, caissons prevailed mainly in the construction of ancestral temples since the midMing Dynasty (sixteenth century). In the Ninghai district only, Zhejiang province, there are more than 120 surviving caissons in ancestral temples. The ancestral temple is the space for sacrifice, and the space underneath the caisson is the most important public setting that was used for the clan's gathering, meeting, and opera performance. The complete edifice was donated and supported by one clan in the village and it usually requested several years of construction. Its refinement and grandiosity demonstrated the capacity and prestige of the clan in the area. As such, the caisson is the most delicate wooden construction in villages. In the Ninghai district, the opera stage is not isolated, but directly connected to the ancestral temple. Moreover, opera stages in the Ninghai district frequently combine two or three caissons (Fig. 7). Detailed information of the collected examples in the field research is listed from Figure 8 to Figure 12.

The Ninghai district is famous for the spiral caisson (Figs 9-11 left), which is constructed in the form

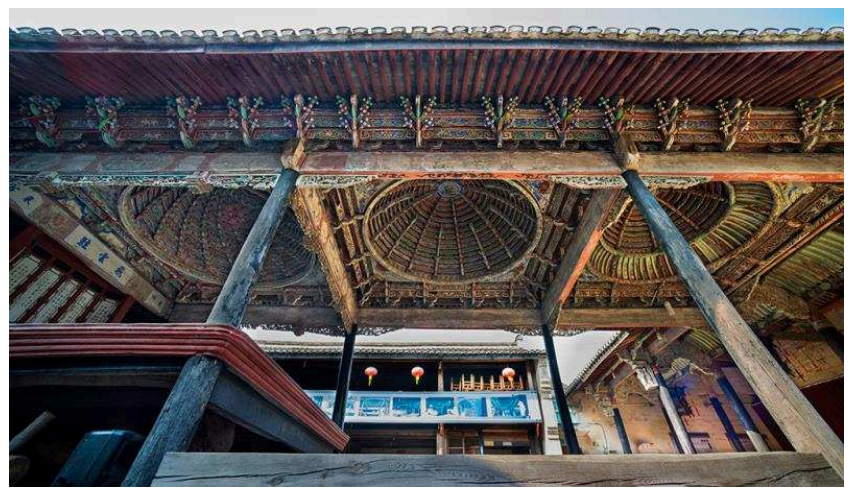

Figure 7. Opera stage in Hu'shi Temple, Ninghai, built in 1920. (C) Peiliang Xu

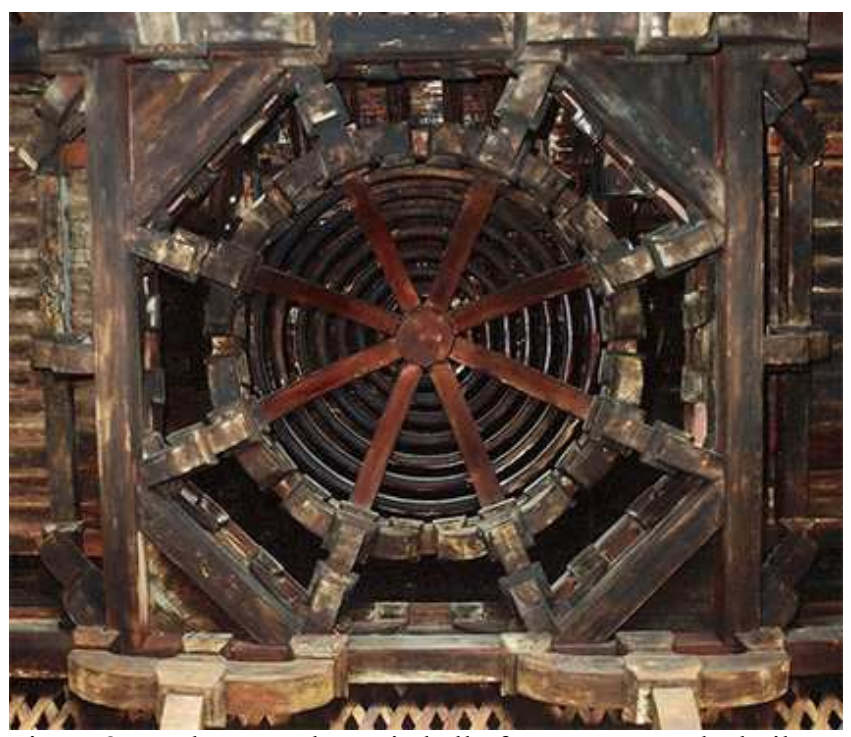

Figure 8. Douba type: the main hall of Baoguo Temple, built ca. 1013. Larger caisson: Height: 0.9 m; Diameter: 1.85 m. Smaller caisson: Height: 0.75 m; Diameter: 1.28 m. Ref. ZJ-01 (C) Peiliang $\mathrm{Xu}$ of a counter clockwise spiral. Besides, the octagonal (Fig. 12) and the round-cap (Fig. 11 right) are also common types in the region. These caissons are of similar sizes, with an average height of $1.5 \mathrm{~m}$, and width and depth of $3.5 \mathrm{~m}$. The caisson in Baoguo Temple (Fig. 8) (Daiyheng 2003), a typical douba example built in 1013, is the earliest known wooden construction in South China. It is a direct precedent of more recent round-cap typologies (Fig. 11 right), which are composed of smaller and more delicate manufactured components. An official mapping has been conducted by the cultural heritage department of the Ninghai district in 2007 (Peiliang 2007). This report includes two-dimensional drawings and information on geometry, carving, painting, and size. Still, no information exists on the structure, construction, and wood-to-wood connections.

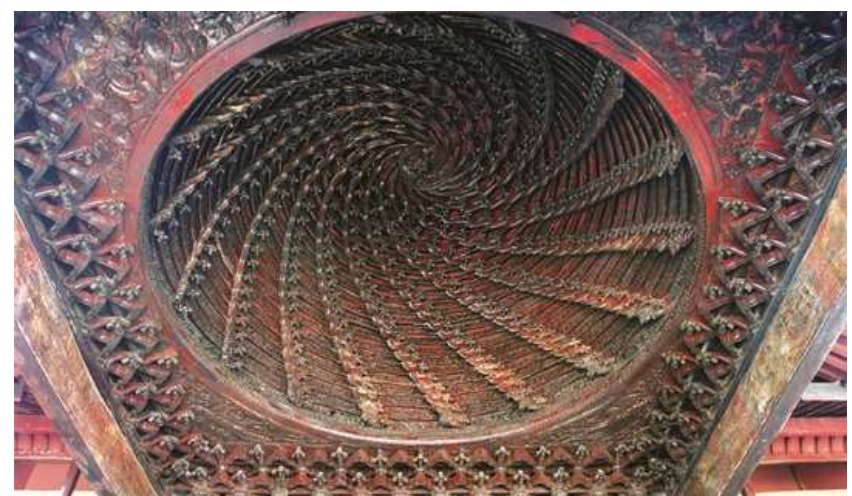

Figure 9. Spiral type: opera stage of Chenghuang Temple, built in 1935. Height: $2.1 \mathrm{~m}$; Diameter: $4.1 \mathrm{~m}$. Ref. ZJ-02 (C) Peiliang $\mathrm{Xu}$

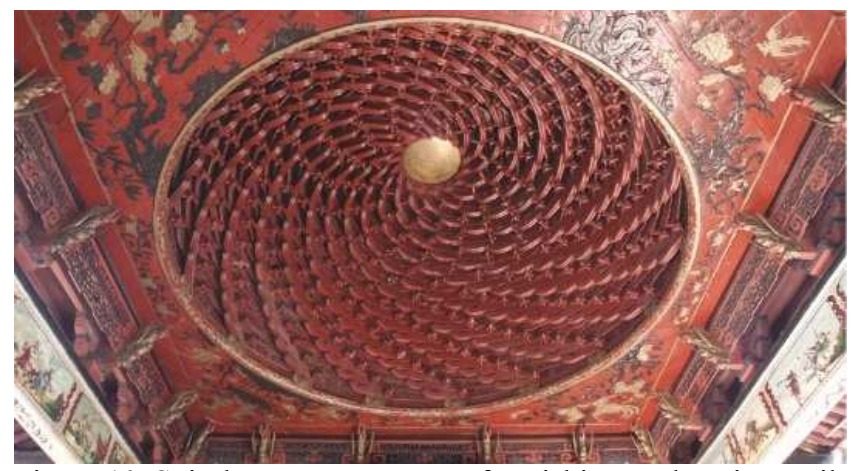

Figure 10. Spiral type: opera stage of Weishi Temple, Xiapu Village, built in 1890. Height: $1.15 \mathrm{~m}$; Diameter: $3.3 \mathrm{~m}$. Ref. ZJ-03 C Jingxian Ye
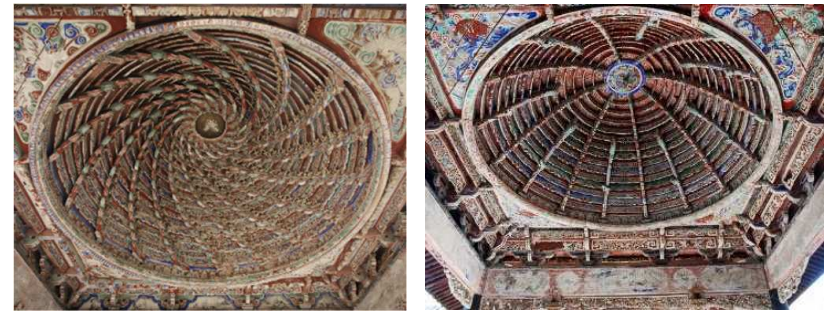

Figure 11. Opera stage of Hushi Temple, Auhu Village, built in the 1920s. Height: 1.38 m; Diameter: 3.45 m. Left: Spiral type. Right: Round-cap type. Ref. ZJ-04A and ZJ-04B (C) Jingxian Ye 


\subsection{Caissons in other provinces}

In addition to the Zhejiang province, Jiangxi (Fig. 14), Fujian and Sichuan provinces are other main distribution areas for the surviving caissons in South China. In form and size, they are similar to the ones in Zhejiang. Web and spider-web (Fig. 13) caissons are local types, mostly on an octagonal base. While the elements of caissons in the Zhejiang province gradually changed from the bottom layer to the top one, the caissons in the Sichuan province are made of similar elements stacked into an even web. Examples of mixed forms also exist, combining web and spiral layouts for instance.

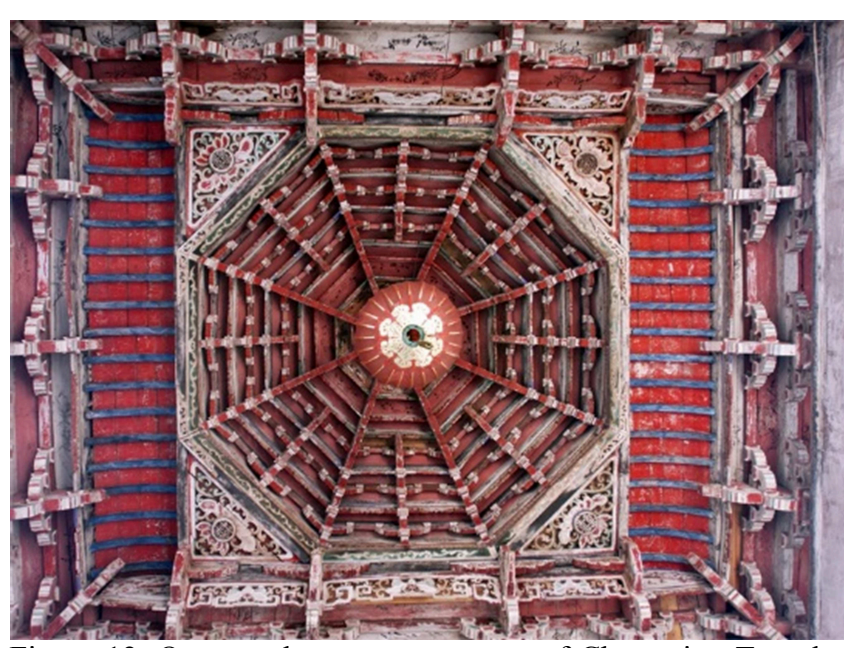

Figure 12. Octagonal type: opera stage of Chongxing Temple, Xidian Village, built in 1841. Height: $1.38 \mathrm{~m}$; Diameter: $2.74 \mathrm{~m}$. Ref. ZJ-05B C Peiliang Xu
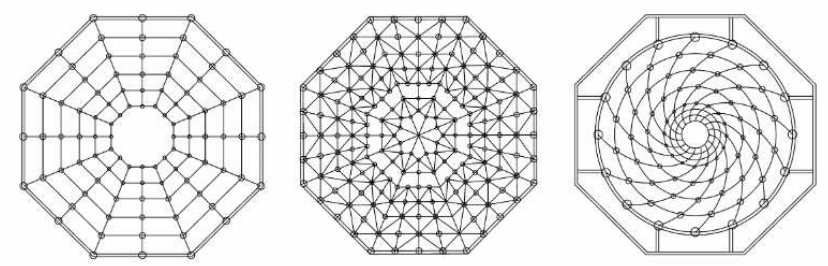

Figure 13. Web type, spider-web type, web-spiral type. (C) Jingxian Ye

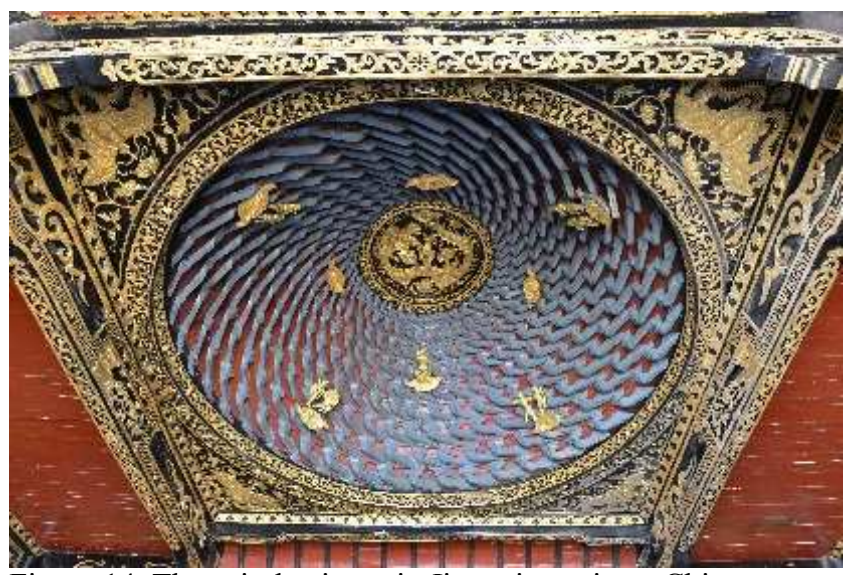

Figure 14. The spiral caisson in Jiangxi province, China (C) Peiliang Xu.
No drawing system similar to those developed in the West exists in traditional Chinese construction.

Original drawings of ancient wooden projects have never been found. A valuable source of sketches resides in Fujian. They are drawn by the local carpenter master Wang Shimeng (1947- ). These sketches mainly concern the relationship and connections between the components, and provide no accurate dimensions.

\section{COMPARISON BETWEEN THE CAISSONS OF OPERA STAGES IN NORTH AND SOUTH CHINA}

Caissons have been extensively built in the opera stages in both North and South China, two regions with different environments and cultures, and hence different practices (Table 1). In general, the existing caissons in North China were built earlier than in the South. The size of northern opera stages is usually much larger. Northern caissons are composed of wooden sticks that cantilever radially, supporting the roof from the rectangular base to the top. Sticks consequently have exposed faces and are apart from each other.

Although southern opera stages are smaller, with an average width and depth of $4.5 \mathrm{~m}$, they are usually divided into a central part and a peripheral base. The central part, of average radius of $1.75 \mathrm{~m}$, is a hemisphere or octahedron made of small elements that cantilever tangentially in a continuous mat. The peripheral base is flat and accommodates the geometry from the outer rectangle to the inner circle or octagon. The southern caissons are structurally independent from the roof, and do not carry other load than their self-weight. Indeed, an additional self-supported roof covers those caissons. Most efforts when designing these caissons were directed towards increasing acoustic performance.

\section{THE SPIRAL CAISSONS IN NINGHAI, ZHEJIANG PROVINCE, SOUTH CHINA}

The spiral caisson is a unique local caisson type of Zhejiang province. In Ninghai, a mountainous region of Zhejiang, there exist many well-preserved ancient wooden spiral caissons. Three of them are here more extensively studied, with regard to geometry, structure, construction, and renovation. They display a variety of geometry and construction techniques that is due to the different completion times, handcraft skills, supports, and materials.

\subsection{Geometry of the spiral type}

Despite of their different sizes, the spiral caissons are usually divided into 16 parts by 16 spiral lines, which 
determine its visual expression. Reference ZJ-03 (Fig. 15 centre) provides a more expressive and dynamic perception because of the intensive movement in the spiral geometry. The form of the hemisphere depends on the components and composition. The height of the members in each layer from bottom to top varies from 8.5 to $9 \mathrm{~cm}$. As an exception, reference ZJ-02 (Fig. 15 left), has 22 layers that are $9.5 \mathrm{~cm}$ high, which is because the diameter of the caisson reaches $4 \mathrm{~m}$, the largest spiral example in Ninghai.

Our field survey showed that the circle was frequently imperfect in geometry, because of a crooked caisson. However, the local carpenters actually do not care about this defect. In Chinese traditional wooden construction, there existed no mapping system with exact dimensions like in the West. Under such conditions, when the Chinese carpenters constructed the form of a circle or a hemisphere, proportions and relationships of the components were valued over accuracy.

\subsection{Structure of the spiral type}

In Ninghai, the roof structure is detached from the caisson, which only supports its own weight (Fig. 16). The square beam frame with the four diagonal beams form an octagonal frame. Every two ridges are positioned on one beam-member through wood-only joinery. The weight of the caisson is evenly distributed

Table 1. Comparison between caissons of opera stages in North and South China.

\begin{tabular}{|c|c|c|}
\hline Items & North China & South China \\
\hline climate & dry & high annual rainfall \\
\hline geography & plain & mountain area \\
\hline seismic zone & yes & no \\
\hline $\begin{array}{l}\text { prevailing } \\
\text { period }\end{array}$ & $\begin{array}{l}\text { from the Yuan to } \\
\text { mid-Ming dynasties } \\
\text { (approx. from } 1300 \text { to } \\
1600 \text { A.D ) }\end{array}$ & $\begin{array}{l}\text { from the mid-Ming } \\
\text { dynasty (approx. } \\
\text { from } 1600 \text { to } 1920 \\
\text { A.D ) }\end{array}$ \\
\hline main types & douba/ reciprocal & $\begin{array}{l}\text { spiral/ octagonal/ } \\
\text { round-cap/web/ } \\
\text { spider web/douba }\end{array}$ \\
\hline $\begin{array}{l}\text { average dimen- } \\
\text { sion of opera } \\
\text { stage }\end{array}$ & $\begin{array}{l}\text { Width: } 7.5 \text { metres } \\
\text { Depth: } 7.5 \text { metres }\end{array}$ & $\begin{array}{l}\text { Height: } 4.5 \text { metres } \\
\text { Width: } 4.5 \text { metres }\end{array}$ \\
\hline $\begin{array}{l}\text { average dimen- } \\
\text { sion of caisson }\end{array}$ & $\begin{array}{l}\text { Width: } 7.5 \text { metres } \\
\text { Depth: } 7.5 \text { metres } \\
\text { Height: } 4 \text { metres }\end{array}$ & $\begin{array}{l}\text { Width: } 3.5 \text { metres } \\
\text { Depth: } 3.5 \text { metres } \\
\text { Height: } 1.4 \text { metres }\end{array}$ \\
\hline supports & $\begin{array}{l}\text { columns (mainly of } \\
\text { wood, some of stone) }\end{array}$ & $\begin{array}{l}\text { columns (mainly of } \\
\text { wood, sometimes } \\
\text { steel or brass) }\end{array}$ \\
\hline \multirow[t]{2}{*}{ structure } & $\begin{array}{l}\text { some openings on the } \\
\text { roof }\end{array}$ & fully enclosed roof \\
\hline & $\begin{array}{l}\text { The caisson works as } \\
\text { the roof structure }\end{array}$ & $\begin{array}{l}\text { The caisson is not } \\
\text { the roof structure }\end{array}$ \\
\hline \multirow[t]{3}{*}{ components } & in large size & in small size \\
\hline & barely carved & very delicate carved \\
\hline & without painting & $\begin{array}{l}\text { with quite exquisite } \\
\text { painting }\end{array}$ \\
\hline acoustic effects & $\begin{array}{l}\text { without acoustic } \\
\text { function }\end{array}$ & $\begin{array}{l}\text { obvious acoustic } \\
\text { quality }\end{array}$ \\
\hline
\end{tabular}

through 16 ridges, each representing a spiral warp line. Accordingly, the spiral form was placed carefully to be able to match the position of the supporting beams on the bottom (Fig. 17). This principle has been applied in the round-cap and octagonal caissons as well.

\subsection{Construction of the spiral type}

The spiral caisson is an addition of three main components (A, B, and C; Figs 18, 20). Component A, the longitudinal cantilever member, and component $\mathrm{B}$, the peripheral curved slat, are assembled up to generate the shape of a hemisphere. Since all ancient caissons are closed, the construction of wood-only connections is not easy to be observed. The following assumption results from our field survey: The component $\mathrm{C}$ works as a wood nail that prevents parts $\mathrm{A}$ and B from lifting up occasionally, although it is insistently considered as a decorative part by the local carpenter master. In other words, the full wooden hemisphere is pined up by these decorative wood nails. Some supportive clues for the assumption can be found on Figure 19.

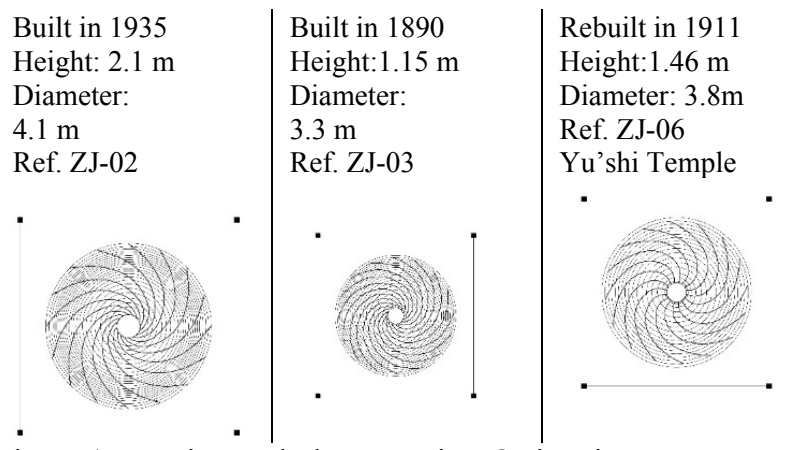

Figure 15. Various spiral geometries. (C) Jingxian Ye

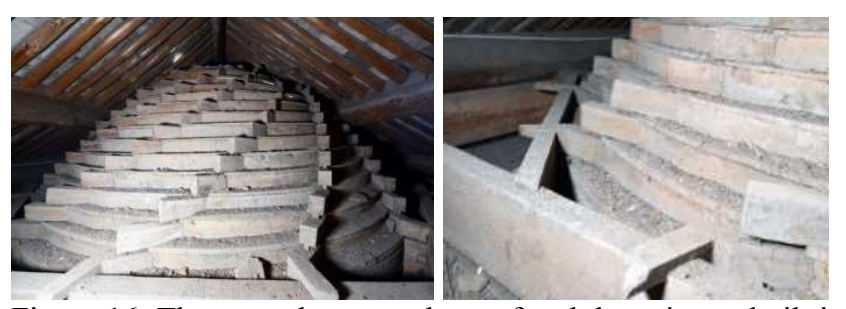

Figure 16. The space between the roof and the caisson, built in the 1920s in Ninghai. Ref. ZJ-04A (C) Jingxian Ye
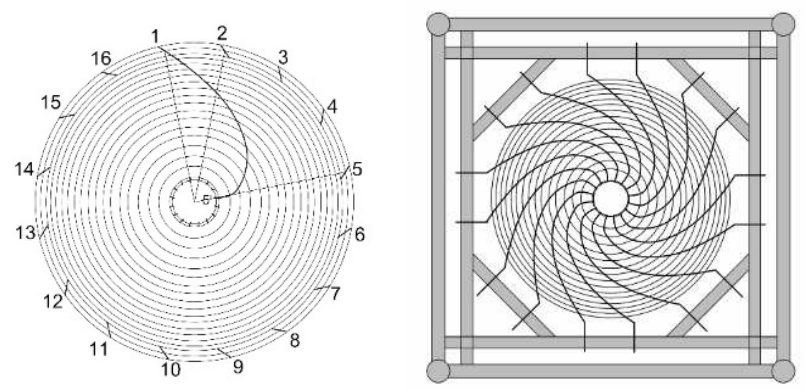

Figure 17. Form-finding principle for the spiral-line and distribution of its weight over the edge beams. (C) Jingxian Ye 
All components C of reference ZJ-04A (Fig. 16), which was built in the 1920s, are fixed on the caisson by steel nails. In some layers, parts $\mathrm{C}$ were even omitted, and the steel nails can be clearly found in the expected position of components C. In this case, part C is definitely a decorative element. Nevertheless, the main connections are still in wood-only joints. From the view of architectural history, the large-scale use of the steel nails appeared after the introduction of modern industry from the West to China. The case is an evidence of the technology transfer about one hundred years ago.

\subsection{Renovation of the spiral caisson}

The restoration of ancient caissons mainly consists in replacing damaged elements. The renovation of the spiral caisson in the opera stage of family Ye's ancestral temple (ZJ-07) is a unique case. It was a thorough process involving disassembly, repair, and reassembly, which provides a rare opportunity to observe the inner structure, construction, and wooden-joints of the spiral type.

Preparation. According to local convention, a sacrificial ceremony is required before the operation, to pray for the blessing of the ancestors. Part of the roof structure over the caisson is first disassembled (Fig.
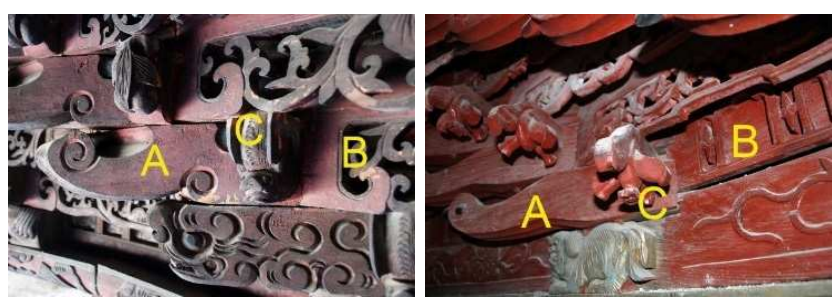

Figure 18. Components A, B, and C. Left: Yushi Temple, Ninghai, Ref. ZJ-06. Right: Weishi Temple, Ninghai, Ref. ZJ-03 (C) Jingxian $\mathrm{Ye}$

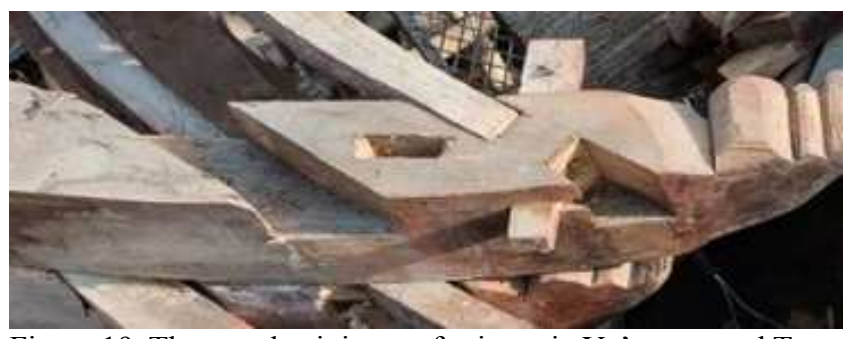

Figure 19. The wooden joinery of caisson in Ye's ancestral Temple, built in 1829, Ninghai, Ref. ZJ-07 (C) Xiaodong Chai

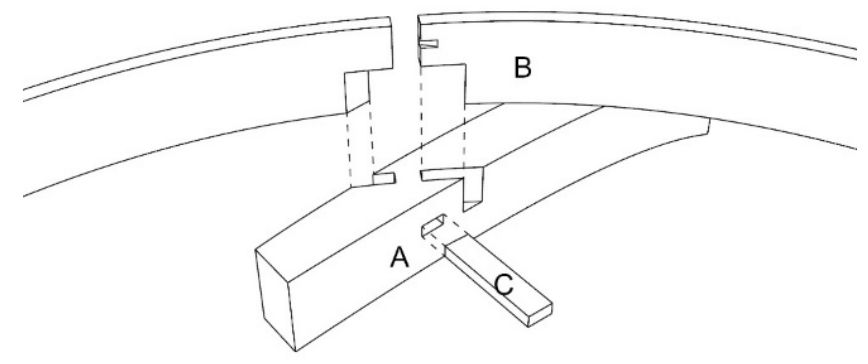

Figure 20. Parts A, B, and C, in Ninghai (C) Jingxian Ye
21). Components such as tiles and wooden beams with good properties are reserved for future reassembly. Several wooden beams are left to be used as a stand for the carpenters during the operation.

Disassembly. It appeared that the top plates of the caisson are fixed with ancient handmade nails (Fig. 22 ), and the rest is constructed with wood-only connections. Layer after layer, the tangential curved slats are removed first, followed by the radial cantilever elements. Each element is numbered clockwise before its dismount. A wooden hammer or stick was used to tap upward to make the wooden construction loose and avoid damage caused by locally concentrated forces during disassembly (Fig. 23). The dismounted components of a same layer (Fig. 24) are tied up together to prevent future confusion (Fig. 25).

Repair and remanufacture. At this stage, each component is checked and cleaned with a brush (Fig. 26). If the damaged area is longer than a third of the whole length, or if the critical joint is seriously destroyed without a possibility of repair, a new component is manufactured and replaces the original one (Figs 27-29). The remaining part is kept as source material for the manufacturing of other small elements.

Reassembly. The assembly sequence is just the reverse of the disassembly sequence, from bottom to top. In order to ensure the fitting of all elements, a trial assembly is performed beforehand. After all the members are installed in place, the gap between each joint is immediately checked (Figs 30-31). The small cracks are filled with tiny lumber, in order to ensure that every node works effectively and a tight construction. The repair or new construction is generally chosen in autumn to avoid the rainy season in South China.

\subsection{The typical construction policy 'Split construction' and 'Zhaomian-Arts'}

A typical construction policy translated as 'split construction', has been carried out for hundreds of years in Ninghai. The traditional Chinese buildings are usually axisymmetric. Along the axis, the part of the project that was first constructed was divided into two parts by the client, who asked two different construction teams to build one half each, including the construction of the structure, the carving, and the painting. Their work would eventually be combined and tightly merged. However, in the meantime, the contrasts in construction and crafts between two sides were easily distinguished. The 'split construction' process consequently allowed the client to pick the best carpenter master out of the two candidates.

Carpentry, carving, and painting normally occupy one-third of the workload separately in a caisson project. The Chinese lacquer of the painting plays an important role in pest controlling. Fine carving and exquisite painting indicate the prestige and wealth of a clan. Without mapping system in the past, a typical 
tool has been developed and used. On several bamboo strips (Fig. 32), the dimensions of all the components were marked in a special approach. Their positional relations are expressed by the unique symbols. The tool is called 'Zhaomian' in Ninghai district, and 'Zhangchi' or 'Gaochi' in other areas. During the construction, the carpenter master would use the Zhaomian to command different craftsmen to work on different members at the same time. The way of measuring and symbolizing changed greatly in different regions and carpenter factions.

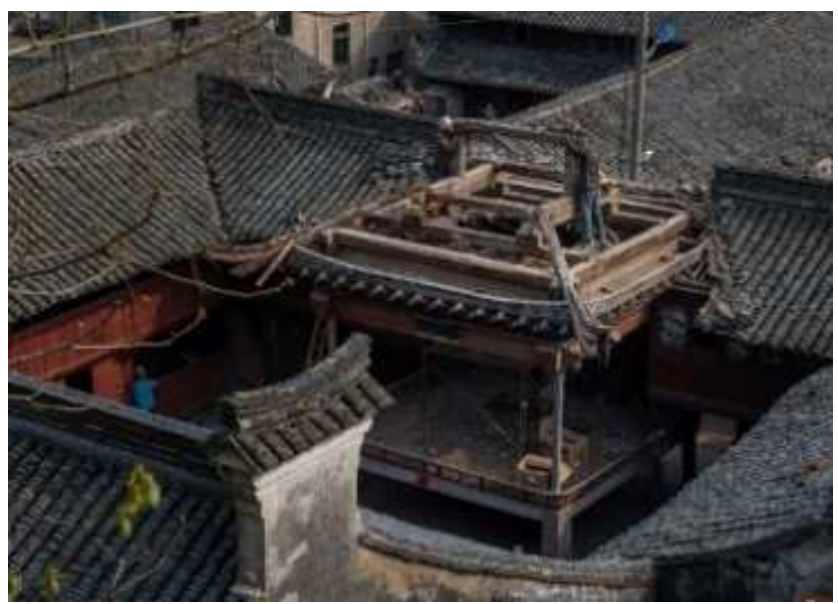

Figure 21. Disassembly of the roof (C) Xiaodong Chai

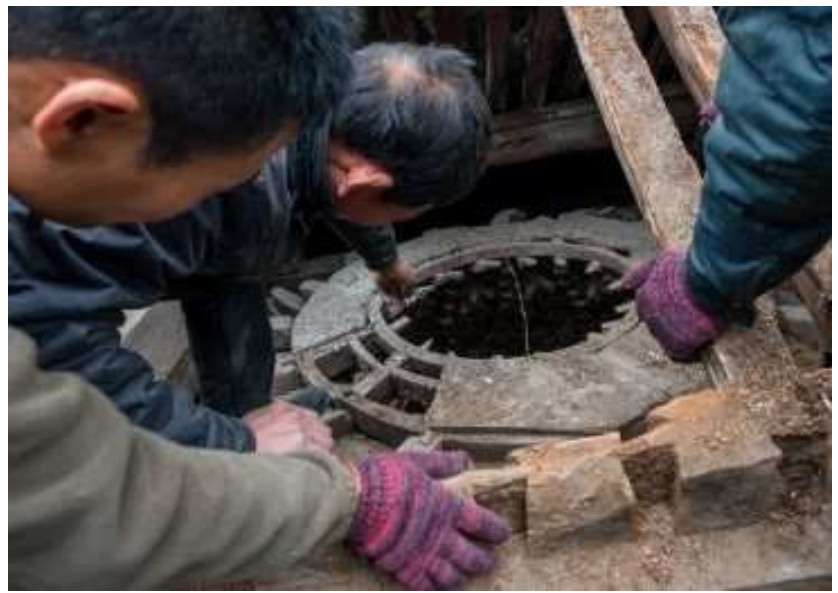

Figure 22. Removal of top plates $\mathbb{C}$ Xiaodong Chai

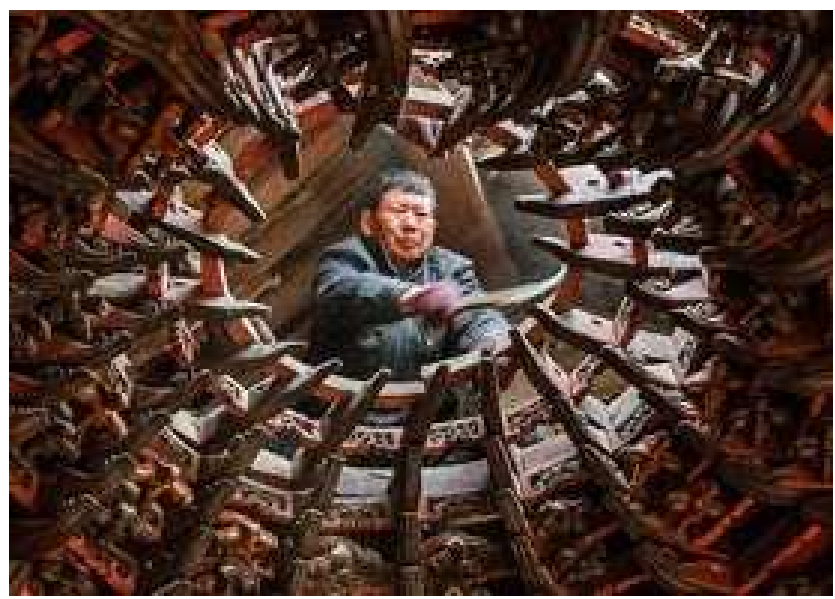

Figure 23. Hammering of the caisson (C) Xiaodong Chai

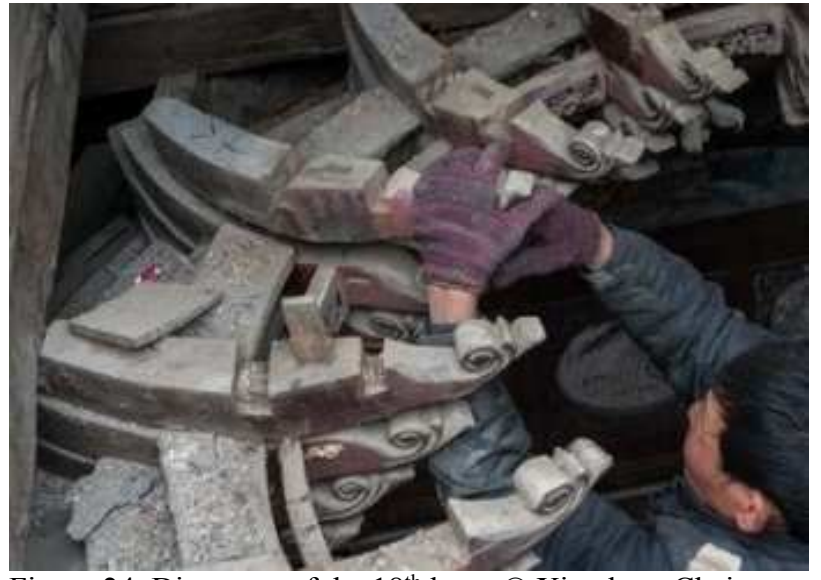

Figure 24. Dismount of the $18^{\text {th }}$ layer (C) Xiaodong Chai

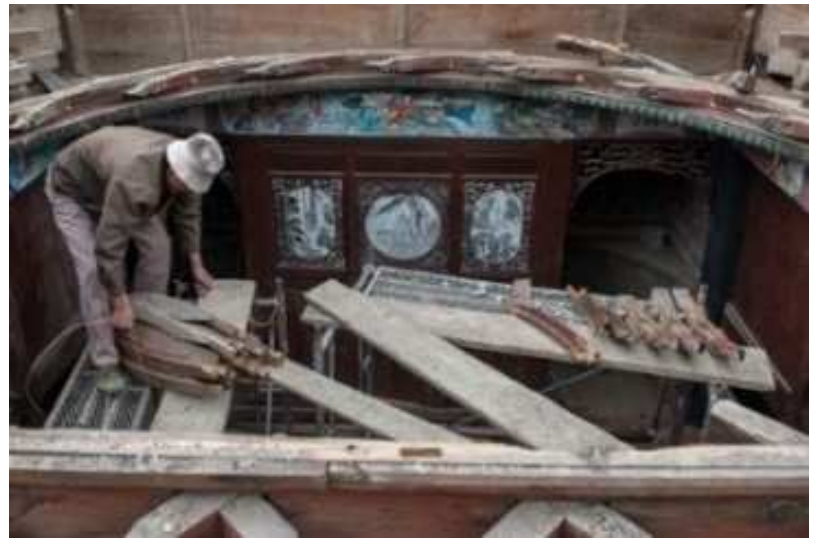

Figure 25.Same-layer components are tied up (C) Xiaodong Chai

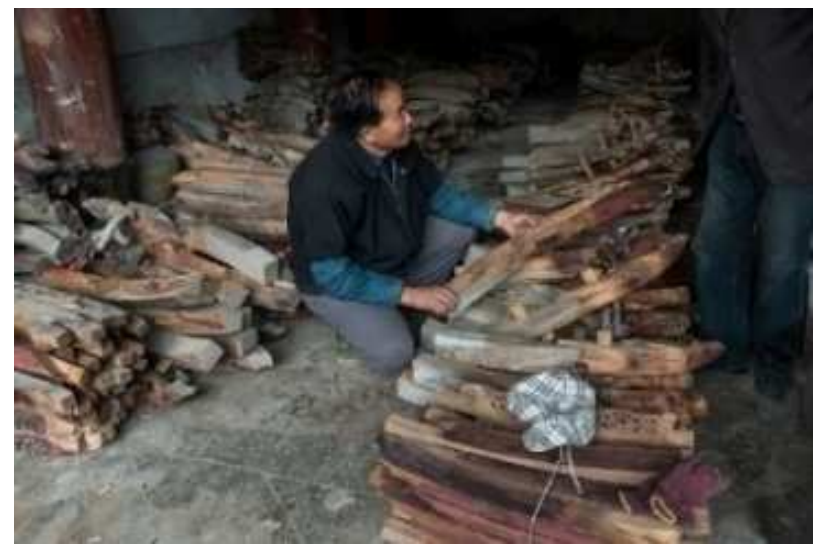

Figure 26. Components are cleaned up (C Xiaodong Chai

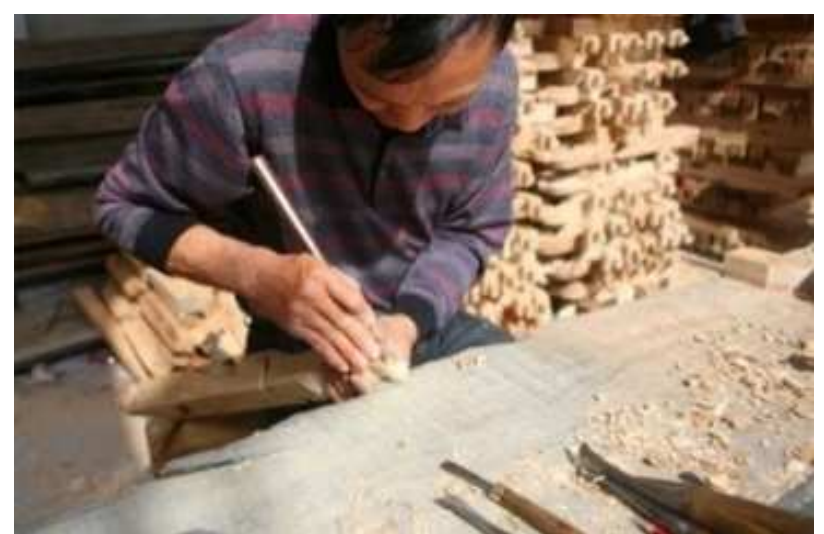

Figure 27. Carving of new cantilever component (C) Yi Zhou 


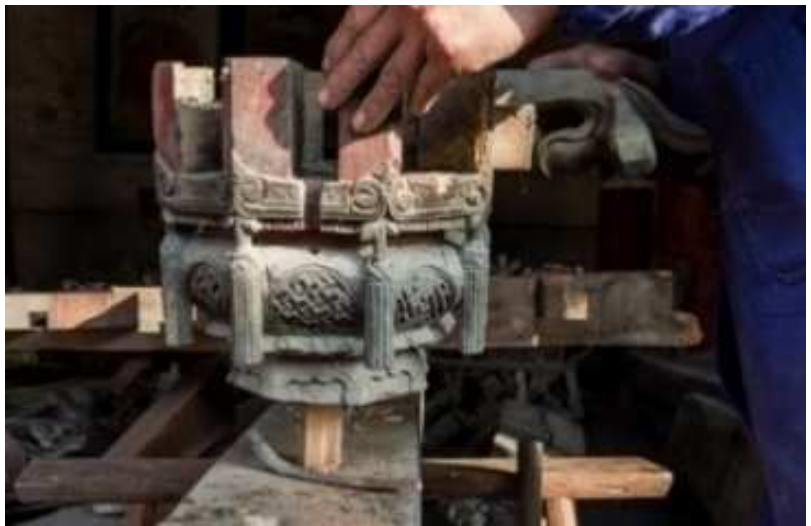

Figure 28. Manufacturing of new tenon tongue (C) Xiaodong Chai

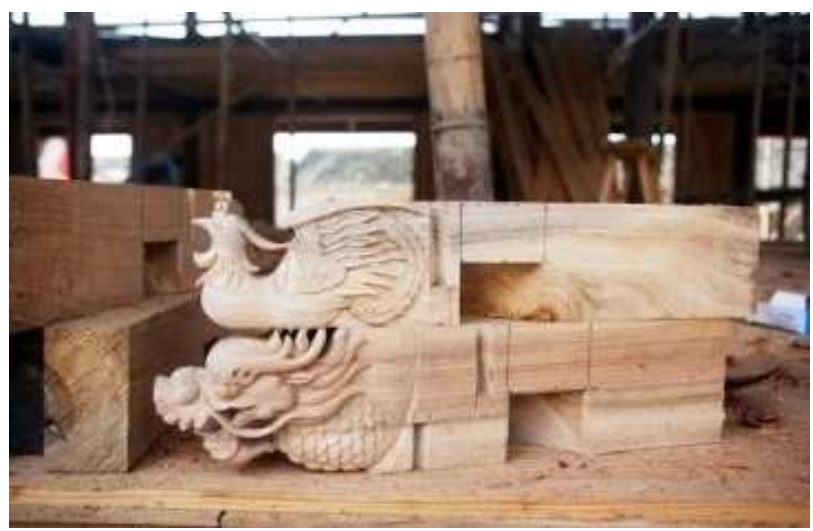

Figure 29. Carved component (C) Yi Zhou

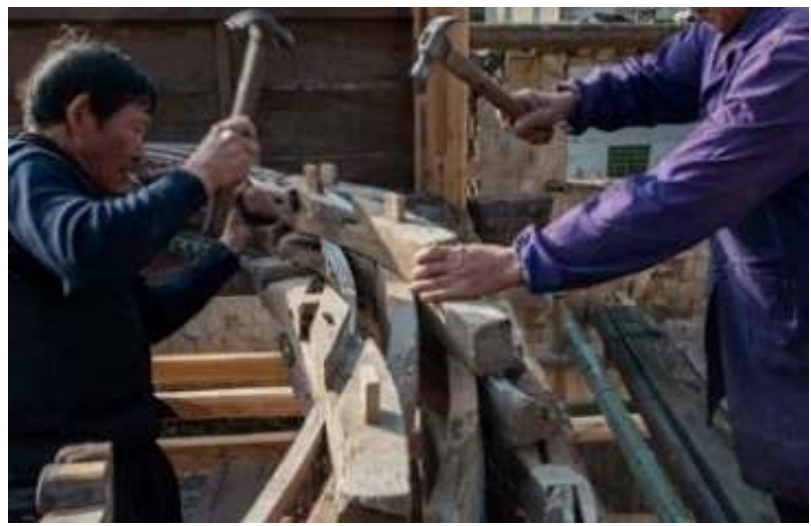

Figure 30. Hammering of the reassembled caisson (C) Xiaodong Chai

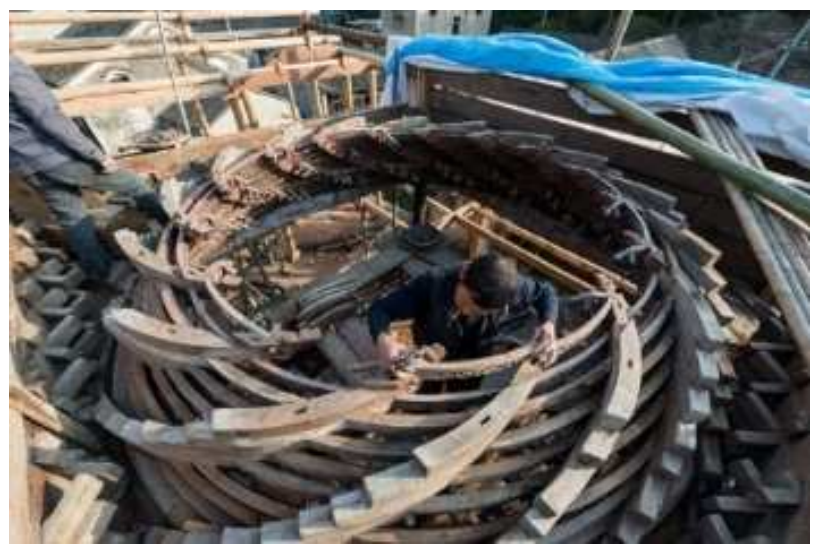

Figure 31. Close to completion (C) Xiaodong Chai

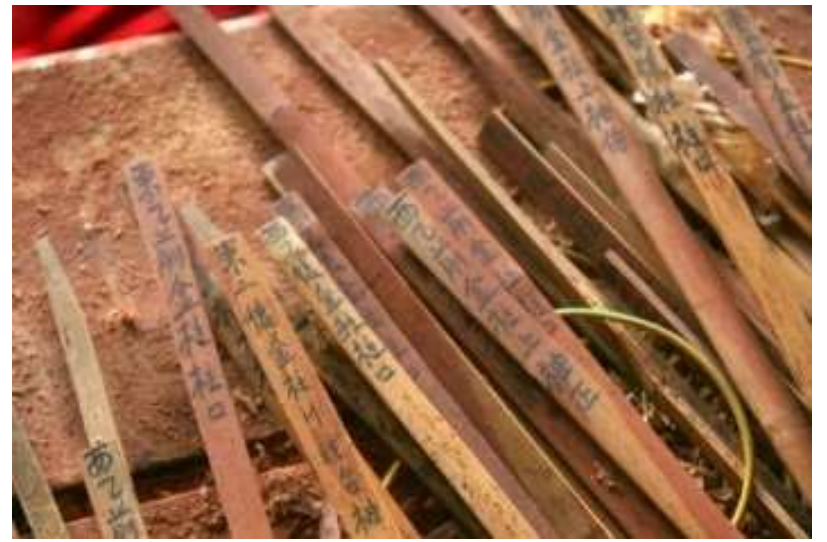

Figure 32. Tool of Zhaomian (C) Yaping Zhang

\section{RESEARCH ON CAISSONS IN CHINA}

\subsection{The first caisson in China}

The earliest known description of caissons' origin in China appeared in the chapter Caisson and ceiling of the book Complete Works of Liang Sicheng VI (Sicheng 2001): "Caissons originally adopted the square-reciprocal-framed structures, which consist of linear wood or stone members, mutually supporting within a closed circuit. This construction enables a wider span and larger height. The skylight or the chimney was placed on the top, like the dwelling in central Asia. In the Han dynasty (202 B.C-220 A.D), the caisson had become a common and mature building part in Chinese architecture, which could be observed in the poems and literature at that time. The caissons in the Mogao Caves and the Yungang Grottoes are the best surviving examples in the Sui and Tang dynasties (581- 907), but in stone." There is currently no agreement on what is the earliest wooden caisson in China. However, it is known that the remaining wooden caissons in China were built after the mid-Tang Dynasty (618-907), since the earliest existing Chinese wooden construction, the Nanchan Temple, was constructed in 782 .

\subsection{Available publications on caissons in China}

The first known mention of a caisson in literature is in Yingzao Fashi, literally "Treatise on Architectural Methods", published in 1110. This treatise is the first publication about construction in Chinese history. It was published to provide a unified set of architectural standards for builders and craftsmen by the government in the mid-Song Dynasty (960-1279). The douba caisson was recorded only in a written form. In another ancient special literature, Gongcheng Zuofa (Municipal engineering practice rules), of the Qing dynasty, the term 'Dragon Well' was merely mentioned. In modern times, the Complete Works of Liang Sicheng (Sicheng 1930s/2001) is the first architectural monograph to refer to the caisson. The Chapter 'Caisson and Ceiling' in Volume VI has provided 
one statement of its origin in China, completed by the scholar LIANG Sicheng (1901-72) according to the dictation of the scholar LIU Zhiping (1909-95) in May 1937. The explanation of ancient text about douba-caisson in Yingzao Fashi has been edited in Volume VII, aiming to help the readers to cross the language barrier. These two descriptions are well known in China. The book The Interpretation of Yinzao Fashi (Guxi 2005) by the scholar PAN Guxi (1928- ) offered some further interpretation of douba caissons.

In the research of some significant ancient buildings, the caissons are commonly mentioned as the roof or ceiling part, such as the ones in Baoguo Temple, Pagoda of Fogong Temple, and Guanyin Pavilion (Mingda 2007). The spider-web caisson was first mentioned in the Xuanluo Pavilion of Sichuan province, which was published in the Journal of Society for the Study of Chinese Architecture in 1930-1945. In recent years, the caisson is usually related to the research on ancient opera stages. However, these studies mainly consider the caissons from the perspective of architectural history, opera history, cultural heritage protection, and acoustic qualities. In the
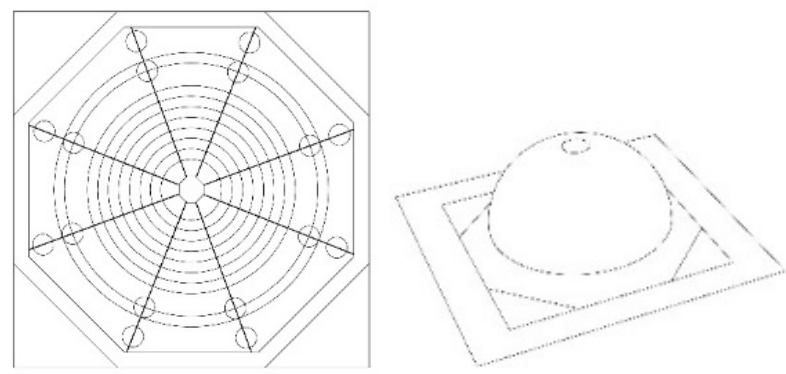

(a) Douba type, with dougong assembly, see Figure 34

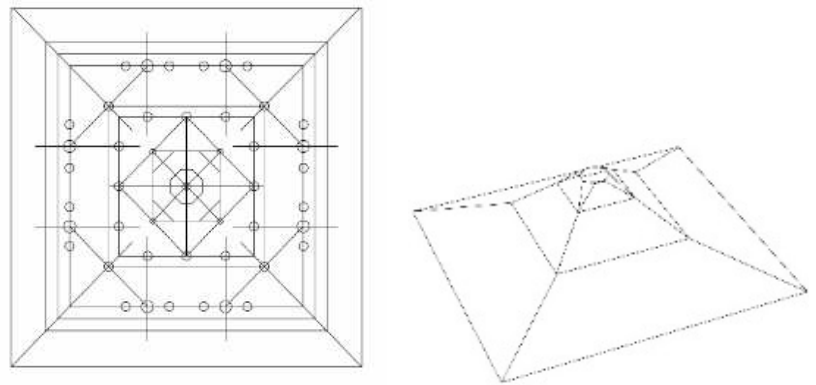

(b) Reciprocal type, with dougong assembly, see Figure 34
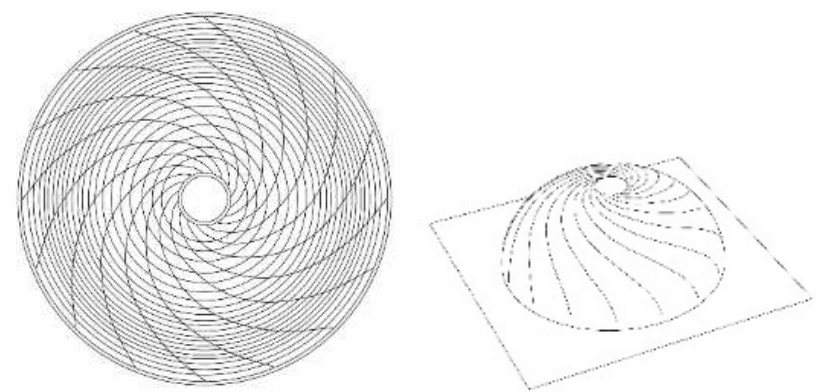

(c) Spiral type; see Figure 20 for assembly past twenty years, scholars from Taiwan have produced some research on the web caisson (Huiyu 2012). Web caissons arouse attention firstly in the biographical study of a critical carpenter master, WANG Yishun (1868-1929), who built and guided some significant wooden edifices in Taiwan in the 1920s. The caisson and its construction are not mentioned until the research on the local 'Gao-chi' technique started (Shuxian 2005) (Xiaoting 2016). Still, caissons are documented in detail in some unpublished reports of conservation works. In 2015, a carpenter master, GUO Hanquan (1945-) introduced the construction of caissons in his book The Techniques of Wooden Construction in South-east China. Based on the author's practical experience, some specific information about components and connections were revealed. However, they were limited only to douba and spiral types.

In conclusion, current authors, all born before 1949 , have especially paid attention to the topic of caisson. Caissons were introduced and discussed from both the viewpoint of architectural history and construction technique, as part of studies on ancient buildings. No comprehensive research on caissons has been formed in the architectural academy yet.

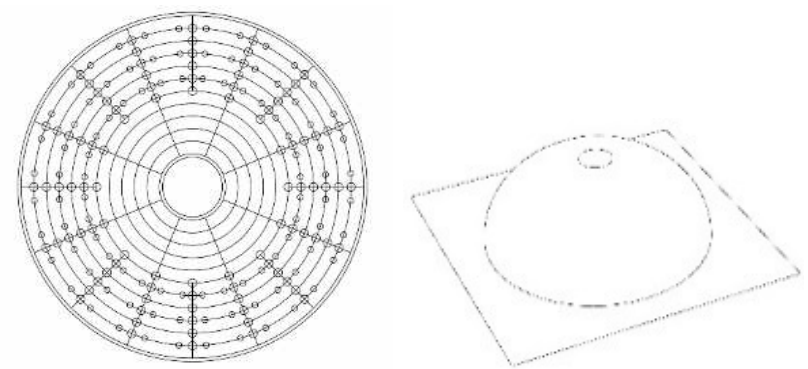

(d) Round-cap type, with dougong assembly, see Figure 34
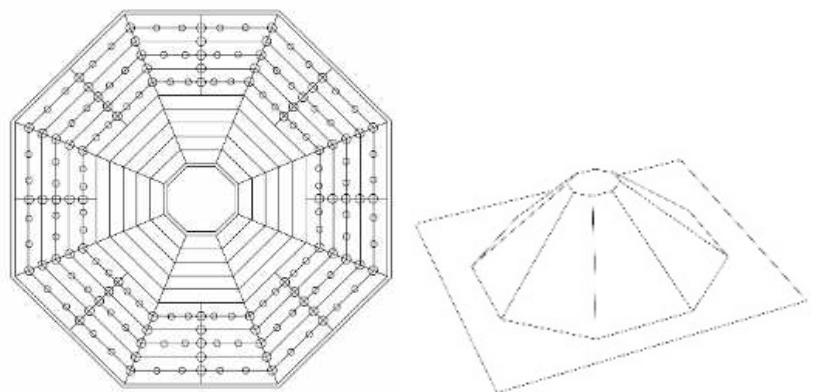

(e) Octagonal type, with dougong assembly, see Figure 34
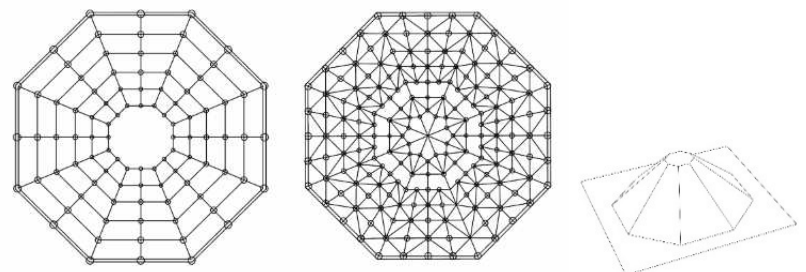

(f) Web type, with dougong assembly, see Figure 34 Figure 33. Classification of caissons (C) Jingxian Ye 


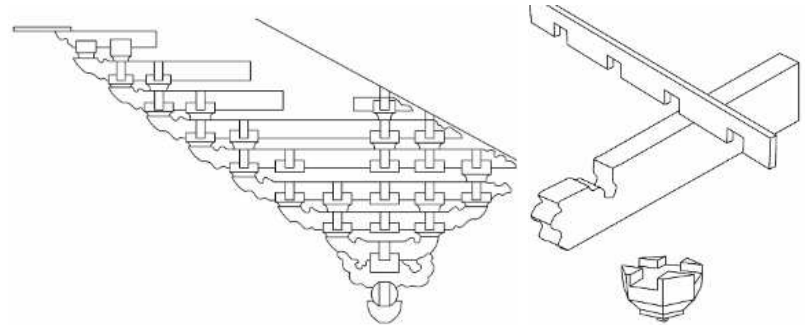

Figure 34. Web type and dougong assembly (C Jingxian Ye

Early architectural literature mainly focused on the douba type. The spiral and spider-web caissons are mentioned only once, separately, up to now. Several other types have been referred to in the contemporary literature of ancient opera stages. No classification of caisson types has been formed as well. Their geometries, forms, construction techniques, and structural behaviours have not been studied scientifically and systematically. In a word, despite numerous exquisite realisations, very little literature is known to exist on the topic, and it lacks comprehensiveness.

\section{CLASSIFICATION OF CHINESE CAISSONS}

Figure 33 is our classification of caissons based on a field investigation and available literature.

\section{CONCLUSION}

Following a field survey and an extensive literature review, this paper brought to light a unique wooden construction typology in China. Although it is well known that timber buildings are outstanding carbonsinks, and appropriate in seismic regions, the complex mechanical behaviour of wooden buildings is still poorly controlled on the stage of design. Therefore, this paper calls for thorough research on this typical timber construction with regards to their construction and structural performance, aiming to promote its preservation and future application in contemporary architecture

\section{ACKNOWLEDGMENTS}

We would like to thank the protectors of these ancient caissons, for their efforts and persistence for decades. We would like to thank the Government of the Ninghai District for helping us visiting the caissons despite traffic and climate inconvenience. We are particularly grateful to the carpenter master Mr. GE Zhaolong who provided first-hand wood-only construction knowledge without reservation. We would like to thank the people who provide us the pictures and information generously. We want to thank all the people who helped us throughout the process.

\section{REFERENCES}

All titles are freely translated from Chinese.

Daiheng, Guo. 2003. Baoguo Temple. Beijing: Cultural Relics Press.

Guxi, Pan, and Jianzhong He. 2005. The Interpretation of Yinzao Fashi. 126-130. Nanjing: Southeast University Press.

Hanquan, Guo. 2015. The Techniques of Wooden Construction in South-east China. 294-318. Beijing: China Architecture \& Building Press.

Huiyu, Huang. 2012. "A Research on the plafond (caisson) of Taipei Confucius Temple”. Master diss., University of Science and Technology of China Taiwan.

Jie, Li. 1110. Yingzao Fashi. China

Jiqin, Wang. 2015. "Some Acoustic Issues in Chinese Traditional Opera Stage”. ACTA ACUSTICA 2015(2):317-330.

Kaiying, Wu, and Deying Luo, etc. 2009. Research and Preservation of the Ancient Chinese Theatrical Stage. Beijing: China Theatre Press.

Mingda, Chen, and Qihen Wang, etc. 2007. Guanyin Pavilion of Dule Temple. Tianjin: Tianjin University Press.

Mingda, Chen. 1966. Pagoda of Fogong Temple. Beijing: Cultural Relics Press.

Peiliang Xu, and Kejun Ying. 2007. The Opera Stages in Ninghai. Beijing: Zhonghua Book Company.

Shuxian, Hong. 2005. "A study on the Gao-chi Arts of Master Carpenter LIANG Shizhi in the Group Xidi of Quan chow". Master diss., Chung Yuan Christian University.

Sicheng, Liang. 2001. Complete Works of Liang Sicheng. Volume VI. 415-421. Beijing: China Architecture \& Building Press.

Sicheng, Liang. 1930s/2001. Complete Works of Liang Sicheng. Volume VII. 213-215. Beijing: China Architecture \& Building Press.

Society for the Study of Chinese Architecture. 1930-1945. Journal of Society for the Study of Chinese Architecture, Volume VII.111-126.Shanghai

Xiaoting, Wu. 2016. "A study on the Gao-chi Arts forMaster Carpenter WANG Shi-meng in the Group Xidi of Quanzhou". Master diss., Huaqiao University. 